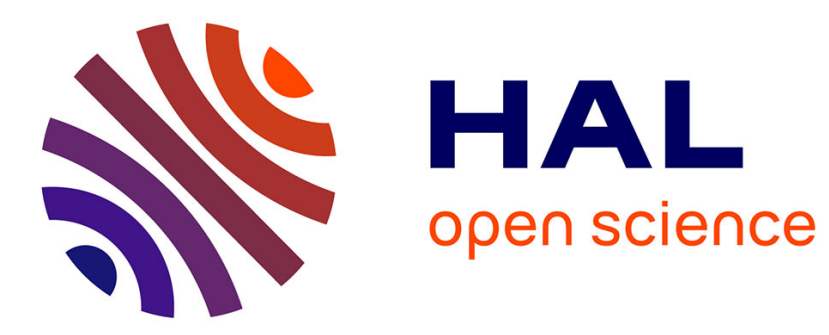

\title{
Environmental Policy Stringency and Technological Innovation: Evidence from Survey Data and Patent Counts
}

Nick Johnstone, Ivan Haščič, Julie Poirier, Marion Hemar

\section{To cite this version:}

Nick Johnstone, Ivan Haščič, Julie Poirier, Marion Hemar. Environmental Policy Stringency and Technological Innovation: Evidence from Survey Data and Patent Counts. Applied Economics, 2011, pp.1. 10.1080/00036846.2011.560110 . hal-00687809

\section{HAL Id: hal-00687809 \\ https://hal.science/hal-00687809}

Submitted on 15 Apr 2012

HAL is a multi-disciplinary open access archive for the deposit and dissemination of scientific research documents, whether they are published or not. The documents may come from teaching and research institutions in France or abroad, or from public or private research centers.
L'archive ouverte pluridisciplinaire HAL, est destinée au dépôt et à la diffusion de documents scientifiques de niveau recherche, publiés ou non, émanant des établissements d'enseignement et de recherche français ou étrangers, des laboratoires publics ou privés. 


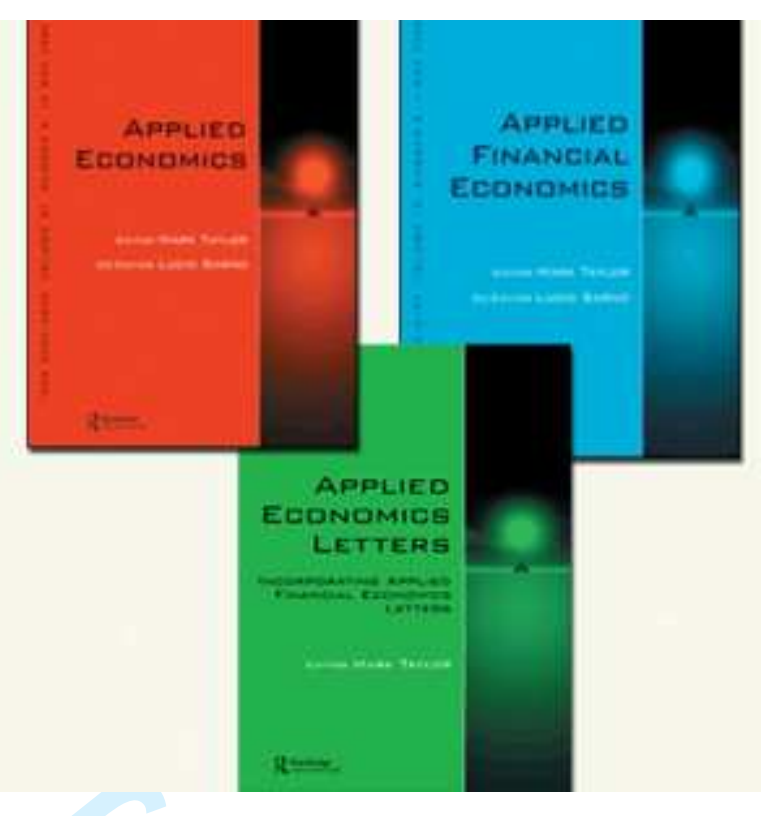

\section{Environmental Policy Stringency and Technological Innovation: Evidence from Survey Data and Patent Counts}

\begin{tabular}{|r|l|}
\hline Journal: & Applied Economics \\
\hline Manuscript ID: & APE-2010-0200.R1 \\
\hline Journal Selection: & Applied Economics \\
\hline Autho Submitted by the & 06-Aug-2010 \\
\hline Complete List of Authors: & $\begin{array}{l}\text { johnstone, nick; OECD, Environment Directorate } \\
\text { Haščč, Ivan; ENSAE } \\
\text { Poirier, Julie; ENSAE } \\
\text { Hemar, Marion; ENSAE }\end{array}$ \\
\hline JEL Code: & $\begin{array}{l}\text { O31 - Innovation and Invention: Processes and Incentives < O3 - } \\
\text { Technological Change|Research and Development < O - Economic } \\
\text { Development, Technological Change, and Growth, O38 - } \\
\text { Government Policy < O3 - Technological Change|Research and } \\
\text { Development < O - Economic Development, Technological Change, } \\
\text { and Growth, Q55 - Technological Innovation < Q5 - Environmental } \\
\text { Economics < Q - Agricultural and Natural Resource Economics, Q58 } \\
\text { - Government Policy < Q5 - Environmental Economics < Q - } \\
\text { Agricultural and Natural Resource Economics }\end{array}$ \\
\hline Keywords: & \begin{tabular}{l} 
Environmental Policy, Technological Innovation, Patents \\
\hline
\end{tabular} \\
\hline
\end{tabular}




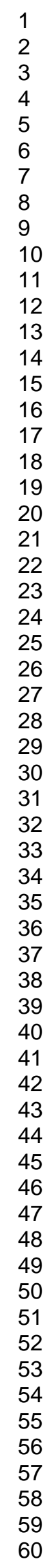

SCHOLARONE ${ }^{m}$
Manuscripts

25

26

27
28

29

30

32

33

34

35

36

37

38

40

41

42

44

45

46

47

48

49

51

52

54

55

57

58

59

60 


\title{
Environmental Policy Stringency and Technological Innovation: Evidence from Survey Data and Patent Counts
}

\author{
Nick Johnstone $^{* 1}$, Ivan Haščič ${ }^{1}$, Julie Poirier ${ }^{2}$, and Marion Hemar ${ }^{2}$ \\ 1. OECD Environment Directorate \\ Empirical Policy Analysis Unit \\ 2 rue André Pascale \\ 75775 Paris cedex 16, France \\ 2. Institut Nationale de la Statistique et des Etudes Economiques \\ 15, bd Gabriel Péri \\ 92245 Malakoff Cedex, France
}

\begin{abstract}
This paper uses patent data to examine the impact of public environmental policy on innovations in environment-related technology. The analysis is conducted using data on an unbalanced panel of 77 countries between 2001 and 2007, drawing upon data obtained from the EPO World Patent Statistical (PATSTAT) database and the World Economic Forum's "Executive Opinion Survey". The results support our hypotheses concerning the positive role of both general innovative capacity and environmental policy stringency on environment-related innovation. A subsequent two-stage model assesses the factors which drive innovation in general and uses the fitted values to estimate environmental innovation. While the analysis is conducted on a smaller sample they confirm the findings of the reduced-form model.
\end{abstract}

JEL codes: O31; O38; Q55; Q58

Keywords: Environmental Policy; Technological Innovation; Patents

*Corresponding author: nick.johnstone@ oecd.org 


\section{Environmental Policy Stringency and Technological Innovation:}

\section{Evidence from Survey Data and Patent Counts}

\section{Introduction}

There is currently much interest in the role of public policy in inducing innovations in technologies which help reduce environmental impacts of economic activity. In many industrialized countries, significant progress has been achieved during the past several decades on this front. For example, emissions of pollutants into air and water have been greatly reduced $^{1}$ and some advances have been achieved in waste management. ${ }^{2}$ Most likely, this has been achieved due to structural changes in economic activity (e.g., less emission-intensive production such as coal fired power plants), input substitution (e.g., using coal with lower sulphur content), as well as via technological improvements (incl. end-of-pipe solutions such as scrubbers, or production process innovations such as fluidized bed combustion).

Understanding the factors that have determined this process is important for several reasons. First, despite significant progress achieved to date, air and water pollution remains an important public policy issue due to its negative impacts on human health and ecosystem functions. Moreover, further emissions reductions will require action on the part of more diffuse sources of pollution and may therefore be more difficult to achieve, as their identification and measurement are complicated. Finally, while emissions of

\footnotetext{
${ }^{1}$ Between 1990 and 2005, emissions of $\mathrm{SO}_{\mathrm{x}}$ and $\mathrm{NO}_{\mathrm{x}}$ have fallen by $72 \%$ and $33 \%$ respectively in the European Union (EU15) and 37\% and 26\% in the US. In some OECD countries emissions have actually increased, notably in Australia and New Zealand with 25\%-58\% increase in emissions. Emissions causing increased levels of water pollution have also been reduced in many countries. For example, the proportion of population connected to public wastewater treatment plants has increased from $46 \%$ to $68 \%$ in OECD countries during the last 25 years. However, enormous differences remain across countries - while as much as $98 \%$ of population is connected in the Netherlands and the UK, the share is only 35\% in Mexico and Turkey (OECD 2007a).

${ }^{2}$ Between 1990 and 2005, the volume of municipal waste generated per capita has remained stable in the US (750 kg), has dropped slightly in Japan (from 410 to $400 \mathrm{~kg}$ ), and has increased sharply in the European Union (EU15) (from 430 to $570 \mathrm{~kg}$ ) (OECD 2007a).
} 
many "traditional" pollutants are currently more-or-less controlled, new "emerging" pollutants may become relatively more important in the future. In this context, technological innovation is important because it allows society to further reduce environmental impacts or to achieve a given environmental goal at lesser cost (see e.g., Kneese and Schultze, 1977).

In the last several decades, OECD countries have introduced a number of policy measures with the objective to reduce environmental impacts of economic activity. However, it is difficult to predict the effect of such policies on the pattern of technological innovation. While private (firm-level) incentives to environment-friendly innovations may play some role $^{3}$, it is public policy that often plays the pivotal role in creating demand for technological innovation in environment-related technologies, although its impact may vary across countries, pollutants, and over time.

In 1932, John Hicks observed that a change in the relative prices of factors of production will motivate firms to invent new production methods in order to economise the use of a factor which has become relatively expensive. This idea, originally developed in the context of labour economics, came to be known as the "induced innovation hypothesis". Applied to the public policy framework, it implies that if governments could affect relative input prices, or otherwise change the opportunity costs associated with the use of environmental resources, firms' incentives to seek improvements in production technology would be increased. Indeed, since markets often fail to put a price on environmental resources, the price of many environmental assets is to a large extent formed by government regulation. Depending on the stringency of regulation, the change in opportunity costs of pollution then translates into increased cost of some factors of

\footnotetext{
${ }^{3}$ For instance, recycling of secondary materials to reduce input costs, consumer demand for 'defensive' measures, etc.
} 
production, and thus incentives to innovate in a manner which saves on the use of these factors.

Since this effect is unobservable to a researcher, a number of imperfect proxies have been used in the literature. This includes reported data on pollution abatement and control expenditure (PACE) measured at the macroeconomic (e.g., Lanjouw and Mody, 1996) or sectoral level (e.g., Brunnermeier and Cohen, 2003), the frequency of inspection visits (e.g., Jaffe and Palmer 1997), parameterisation of policy types (e.g., Fischer and Newell, 2008), or various derived measures based on survey data which elicit information on the perceptions of the regulated community (e.g., Johnstone, 2007).

While theoretical work has shown that environmental regulation may provide incentives for technological improvements (e.g., Milliman and Prince 1989; Downing and White 1986), empirical evidence on the effect of stringency of environmental policy on innovative behaviour remains limited, both with respect to the overall effects of environmental policy on technological innovation as well as the more specific question of the extent to which this is reflected in patent activity. Nevertheless, there is now increasing empirical evidence to support the contention that environmental policies do lead to technological innovation. For recent reviews of the empirical literature on this theme see Popp et al. (2009), Jaffe et al. (2002) and Vollebergh (2007).

In this paper, we use data on perceived stringency as alternative measures of regulatory stringency. The effects of public environmental policy and other factors on innovation in environmental technologies are analysed using patent data for an unbalanced panel of 77 countries for the period 2001-2007. Unlike previous studies which are sectoral in their focus, this econometric study uses innovation and policy stringency measures at the cross-country level. The key hypothesis to be explored is the effect of public environmental policy on innovation. However, since environmental innovation is likely to 
be a consequence of general innovative capacity, we also assess the role of the factors which induce more general innovation.

\title{
II. Data construction and interpretation
}

\section{Patent counts as a measure of environment-related innovation}

\begin{abstract}
As noted above, we use patent data to construct a measure of environmental innovation. Patent data have been used as a measure of technological innovation because they focus on outputs of the inventive process (Griliches, 1990; OECD, 2009). This is in contrast to many other potential candidates (e.g. research and development expenditures, number of scientific personnel, etc.) which are at best imperfect indicators of the innovative performance of an economy since they focus on inputs. Moreover, patent data provide a wealth of information on the nature of the invention and the applicant, the data is readily available (if not always in a convenient format), discrete (and thus easily subject to statistical analysis). Significantly, there are very few examples of economically significant inventions which have not been patented (Dernis and Guellec, 2001). Most importantly for this study, they can be disaggregated to specific technological areas.
\end{abstract}

Drawing upon existing efforts to define 'environmental' activity in sectoral terms, some previous studies have related patent classes to industrial sectors using concordances (e.g., Jaffe and Palmer, 1997). The weaknesses of such approach are twofold. First, if the industry of origin of a patent differs from the industry of use of the patent, then it is not clear to which industrial sector a patent should be attributed in the analysis. This is important when studying specifically 'environmental' technology because in this case the demand (users of technology) and supply (inventors of technology) of environmental innovation may involve different entities. Often, "environmental" innovations originate in industries which are not specifically environmental in their focus. For example, 
technologies aimed at reducing wastewater effluents from the pulp \& paper industry are often invented by the manufacturing or chemicals industry (see e.g., Popp et al., 2007). On the other hand, some 'environmental' industries invent technologies which are widely applicable in non-environmental sectors (e.g., sorting of waste; separation of vapours and gases).

More fundamentally, sectoral classifications are, by definition, based on commercial outputs. As such there will be a bias toward the inclusion of patent applications from sectors that produce environmental goods and services. The application-based nature of the patent classification systems allows for a richer characterization of relevant technologies. Consequently, in this study patent classifications are used, rather than those of industrial or sectoral classifications. This allows for a precise measure of innovation. While Jaffe and Palmer (1997) used patent totals (environmental and non-environmental patents) to study the effect of environmental regulation on innovation, Brunnermeier and Cohen (2003) focus on environmental patents only, and their approach is thus similar to ours. However, in their paper they focus on patents from a single office in a single country (the United States). While some papers have drawn upon data from a crosssection of countries, their focus is much narrower. For instance, Popp (2006) looks at the specific case of NOx regulation, while Johnstone et al. (2010) focus on renewable energy technologies. For a thorough review of the literature and related empirical papers see OECD (2008).

Patent data were extracted from the EPO World Patent Statistical (PATSTAT) database (EPO 2008) using a search algorithm based on a selection of IPC classes which target specific areas of environment-related technology (see Annex 1 for a list of the classes 
used). ${ }^{4}$ From the population of patent applications deposited worldwide, we only include the 'claimed priorities' because these are considered to be the high-value applications. ${ }^{5}$ The patent data are used to construct counts of patent applications in selected areas of environmental technology (air pollution, water pollution, solid waste management), classified by inventor country (country of residence of the inventor) and priority date (the earliest application date within a given patent family). A panel of patent counts for a cross-section of all countries and over a time period of 1975-2006 was obtained.

Figure 1 shows patenting activity in the three environmental domains. Overall, these data suggest a certain level of maturity of this technological field. In particular, innovations related to solid waste management reached a peak in 1993 and have declined since. For water pollution control technologies the peak is in the late 1990s. Finally, only in the case of air pollution control innovations have been increasing rapidly until very recently, keeping pace with the growth in patenting overall (shown on the right-hand axis).

\footnotetext{
${ }^{4}$ The selection of classifications benefited from searches developed by Lanjouw and Mody (1996) and Schmoch (2003). The methodology can be found at www.oecd.org/environment/innovation/indicator .

${ }^{5}$ Claimed priority is an invention for which a patent application has been deposited at an additional office to that of the 'priority office'. In other words, these are inventions that have been applied for protection in multiple countries (patent family size $>1$ ). See Guellec and van Pottelsberghe (2000) and Harhoff et al. (2003) for empirical evidence supporting this approach.
} 
Figure 1. General 'Environmental' Technologies by Environmental Medium

(Number of patent applications - claimed priorities, worldwide)

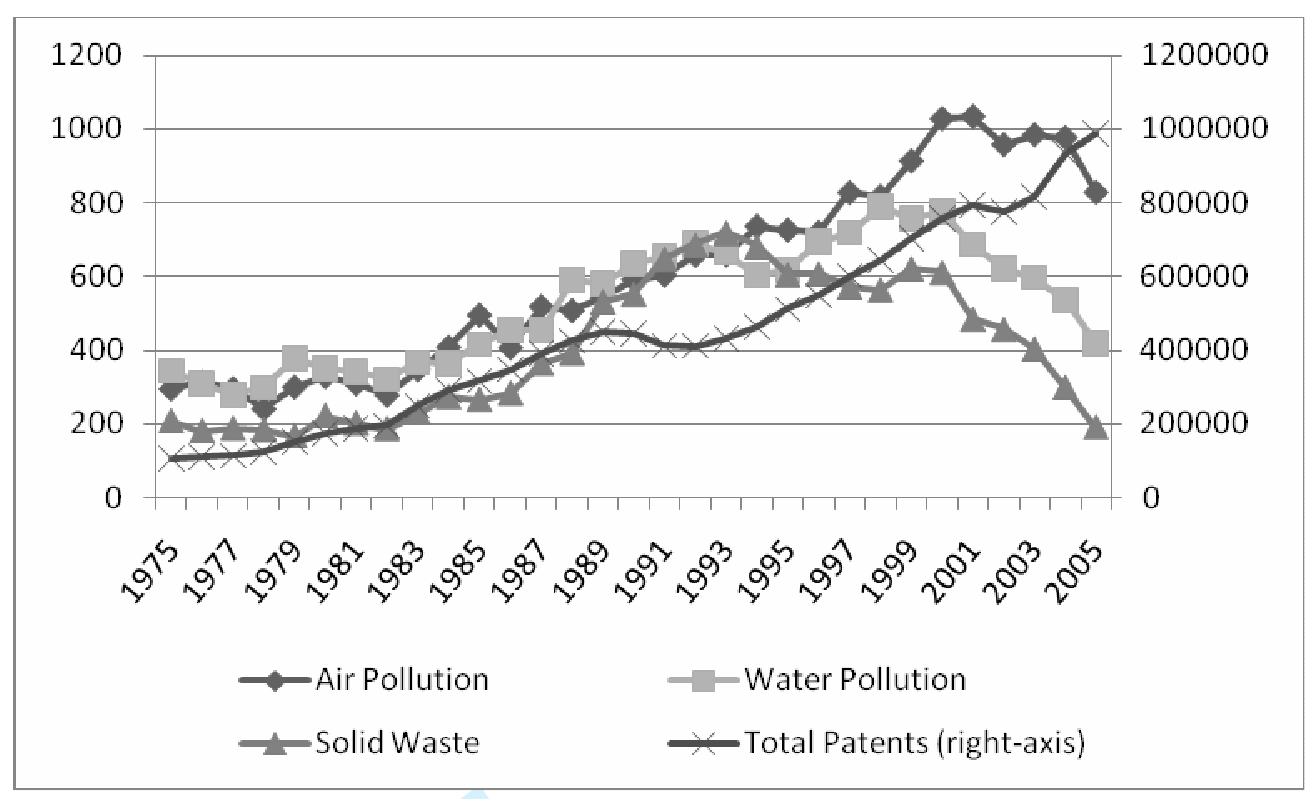

Figure 2 gives patent counts in environmental technology for selected countries which have exhibited particularly significant levels of innovation. Germany had the highest number of general environmental patents, with Japan and the US following, until the midnineties, when Japan took over leadership. Together with France and the UK, these five countries represent $76 \%$ of patent applications in the three domains together. Germany alone is responsible for the highest number of filings in water and waste, while air pollution control is dominated by Japan. 
Figure 2. General 'Environmental' Technologies by Inventor Country (Number of patent applications - claimed priorities, worldwide; 3-year moving average)

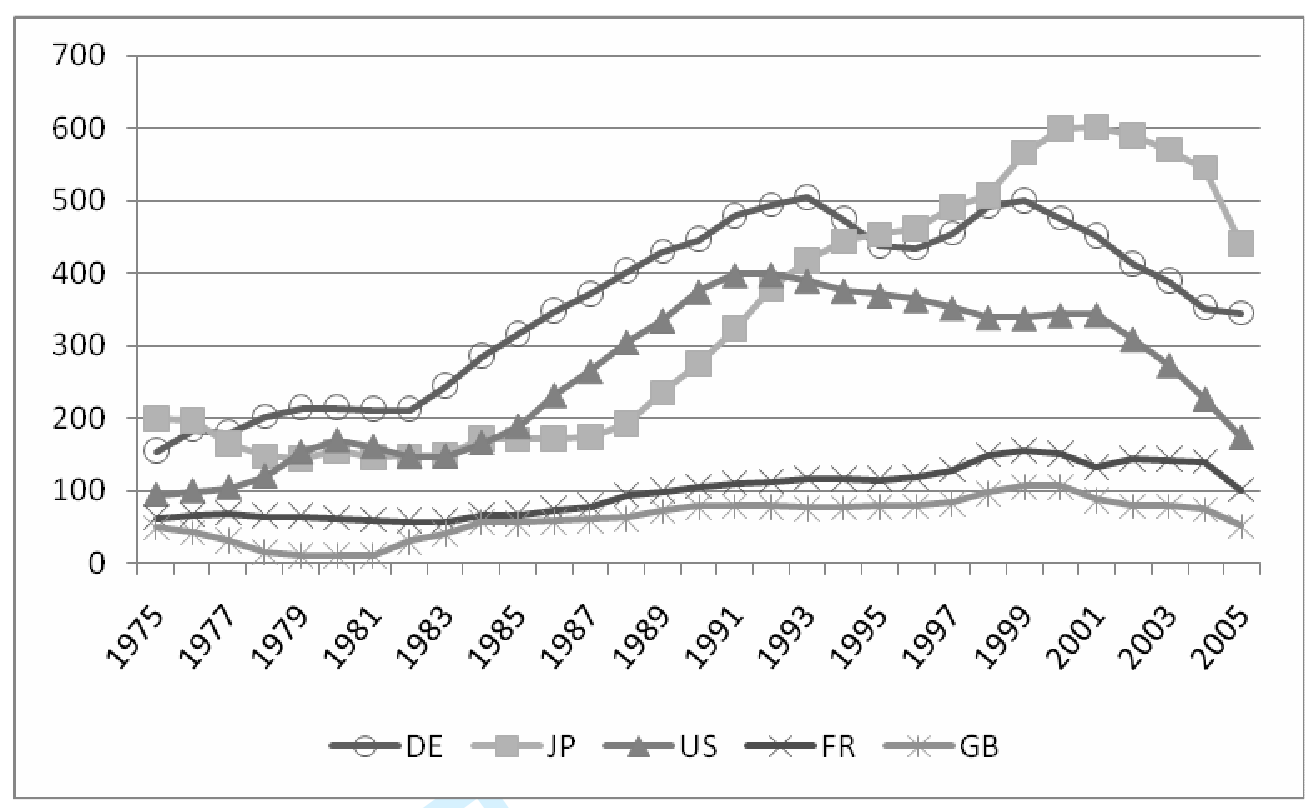

While Germany, Japan, the US, France and the UK are consistently important in environmental technologies examined, other significant innovators in specific areas have included Sweden (air), Canada (water, waste), the Netherlands (water, waste), and Italy (waste). However, a comparison of the productivity of inventive activity across countries needs to account for relative differences in the size of countries' scientific capacity and effort. $^{6}$ In Table 1, the counts are weighted by country's gross domestic expenditure on $R \& D$ to yield a measure of patent intensity. On this basis, a number of smaller countries such as Austria, Finland, or Norway rank highly.

\footnotetext{
${ }^{6}$ For example, Madsen (2007) used the ratio of patents and real R\&D expenditures as an indicator of countries' research productivity.
} 
Table 1. Environmental Patents per Dollar of General R\&D (2001-03)

(Number of 'environmental' patent applications - claimed priorities worldwide; Gross domestic expenditures on R\&D in USD billions ( $\left.10^{9}\right)$ using PPP and 2000 prices)

\begin{tabular}{|c|c|c|c|c|}
\hline & Air & Water & Waste & $\begin{array}{l}\text { Env. tech. } \\
\text { combined } \\
\text { (AWW) }\end{array}$ \\
\hline Germany & 4.49 & 2.03 & 1.32 & 7.68 \\
\hline Austria & 1.85 & 2.54 & 2.47 & 6.33 \\
\hline Finland & 1.93 & 2.53 & 1.82 & 6.07 \\
\hline Japan & 3.69 & 1.26 & 0.93 & 5.70 \\
\hline France & 1.88 & 1.46 & 0.85 & 4.12 \\
\hline Norway & 0.75 & 1.94 & 1.02 & 3.83 \\
\hline Luxembourg & 2.37 & 1.19 & 0.79 & 3.56 \\
\hline Netherlands & 0.59 & 1.43 & 1.35 & 3.40 \\
\hline Belgium & 0.83 & 1.21 & 1.40 & 3.32 \\
\hline New Zealand & 0.33 & 1.65 & 1.32 & 3.30 \\
\hline Sweden & 1.70 & 0.87 & 0.75 & 3.23 \\
\hline Hungary & 0.52 & 1.29 & 1.55 & 3.10 \\
\hline Canada & 0.83 & 1.21 & 1.14 & 3.00 \\
\hline Czech Republic & 0.34 & 0.80 & 1.89 & 2.86 \\
\hline Slovak Republic & 0.00 & 0.66 & 2.20 & 2.86 \\
\hline United Kingdom & 0.83 & 1.23 & 0.76 & 2.77 \\
\hline Korea & 1.10 & 1.16 & 0.65 & 2.77 \\
\hline Australia & 0.33 & 1.56 & 1.10 & 2.76 \\
\hline Italy & 0.79 & 0.88 & 1.14 & 2.67 \\
\hline Denmark & 0.47 & 1.22 & 0.60 & 2.30 \\
\hline Poland & 0.00 & 1.02 & 1.04 & 2.06 \\
\hline Greece & 0.00 & 1.71 & 0.79 & 1.98 \\
\hline Spain & 0.14 & 0.96 & 0.52 & 1.62 \\
\hline Israel & 0.20 & 0.77 & 0.47 & 1.38 \\
\hline Slovenia & 0.64 & 0.64 & 0.00 & 1.27 \\
\hline Taiwan & 0.30 & 0.56 & 0.49 & 1.23 \\
\hline United States & 0.54 & 0.40 & 0.24 & 1.15 \\
\hline Ireland & 0.32 & 0.36 & 0.48 & 0.93 \\
\hline Russia & 0.25 & 0.41 & 0.23 & 0.83 \\
\hline Singapore & 0.12 & 0.53 & 0.06 & 0.65 \\
\hline South Africa & 0.28 & 0.14 & 0.21 & 0.63 \\
\hline Mexico & 0.26 & 0.13 & 0.13 & 0.52 \\
\hline Iceland & 0.00 & 0.45 & 0.00 & 0.45 \\
\hline Romania & 0.31 & 0.00 & 0.00 & 0.31 \\
\hline Portugal & 0.12 & 0.12 & 0.00 & 0.24 \\
\hline China & 0.07 & 0.10 & 0.07 & 0.21 \\
\hline Argentina & 0.13 & 0.00 & 0.00 & 0.13 \\
\hline
\end{tabular}

\section{Regulatory stringency}

In previous work on the determinants of environmental innovation, relative policy stringency has been included as the principal environmental policy factor (see, for example, Brunnermeier and Cohen, 2003 and Lanjouw and Mody, 1996). The relative stringency of environmental policy is thought to induce innovation by changing relative factor prices (the idea, discussed in terms of labor costs, goes back to Hicks 1932). For 
instance, an environmentally-motivated tax would raise the price of the emission targeted, inducing innovation which is emission-saving. (See Crabb and Johnson, 2007 for a discussion of the effects of fuel taxes on motor vehicle fuel efficiency innovations.) However, in the context of environmental policy, many regulations take the form of production constraints rather than explicit price changes. While the effect is analogous changing the opportunity costs of the use of the environmental resource - measurement is often more difficult.

Moreover, in the context of a study which cuts across sectors and countries, data on regulatory stringency is unlikely to be commensurable. Public policies in different countries typically target specific environmental impacts (pollutants) using a specific policy instrument. This paper deals with a broadly-defined (environmental) technology and hence covers multiple impacts and potentially a wide spectrum of policy instruments and sectors. Moreover, it operates in a cross-country context. In many of the previous studies mentioned, data on pollution abatement and control expenditures (PACE) have been used to measure policy stringency. However, in a cross-country study such a variable is inappropriate due to the heterogeneity in the definitions used and sampling strategies. For instance, in some countries the expenditures of 'specialised' firms in the environmental goods and services sector are included, while in other countries this is not the case. ${ }^{7}$ In addition, there are large numbers of missing observations resulting in a very small panel.

And finally, the use of PACE data is conceptually inappropriate, since there is no necessary correlation between abatement expenditures and regulatory stringency. Several reasons have been identified in the literature, including (a) the difficulty of identifying expenditures on environmental compliance compared to what they would have been in

${ }^{7}$ See OECD (2007b) for a discussion. 
the absence of environmental regulations. The difficulty of establishing an appropriate baseline arises because even in the absence of government regulation firms may still invest in such projects in order to limit their potential exposure to liability and improve their environmental image with customers (Jaffe et al., 1995). Another concern associated with the use of aggregate measures of PACE to proxy for stringency relates to crosscountry differences in industrial composition. Countries with a lot of polluting industry will have relatively high environmental compliance costs, regardless of the stringency of their regulations (Levinson, 1999)

In this study, data from the World Economic Forum's "Executive Opinion Survey" is used to measure policy stringency. The survey was implemented by the WEF's partner institutes in over 100 countries, which include departments of economics at leading universities and research departments of business associations. The means of survey implementation varied by country and included postal, telephone, internet and face-toface survey. In most years, there were responses from between 8,000 and 10,000 firms (see WEF 2008 for a description of the sampling strategy.) Respondents are asked a number of questions related to environmental policy design. In particular, the degree of perceived stringency of a country's overall environmental regulation was assessed on a Likert scale, with $1=$ lax compared with that of most other countries, and $7=$ among the world's most stringent. Mean responses for 40 selected countries from our sample are provided in Figure 3. 
Figure 3. Stringency of Environmental Policy Regimes in Selected Countries (Mean value of the index over 2001-2007)

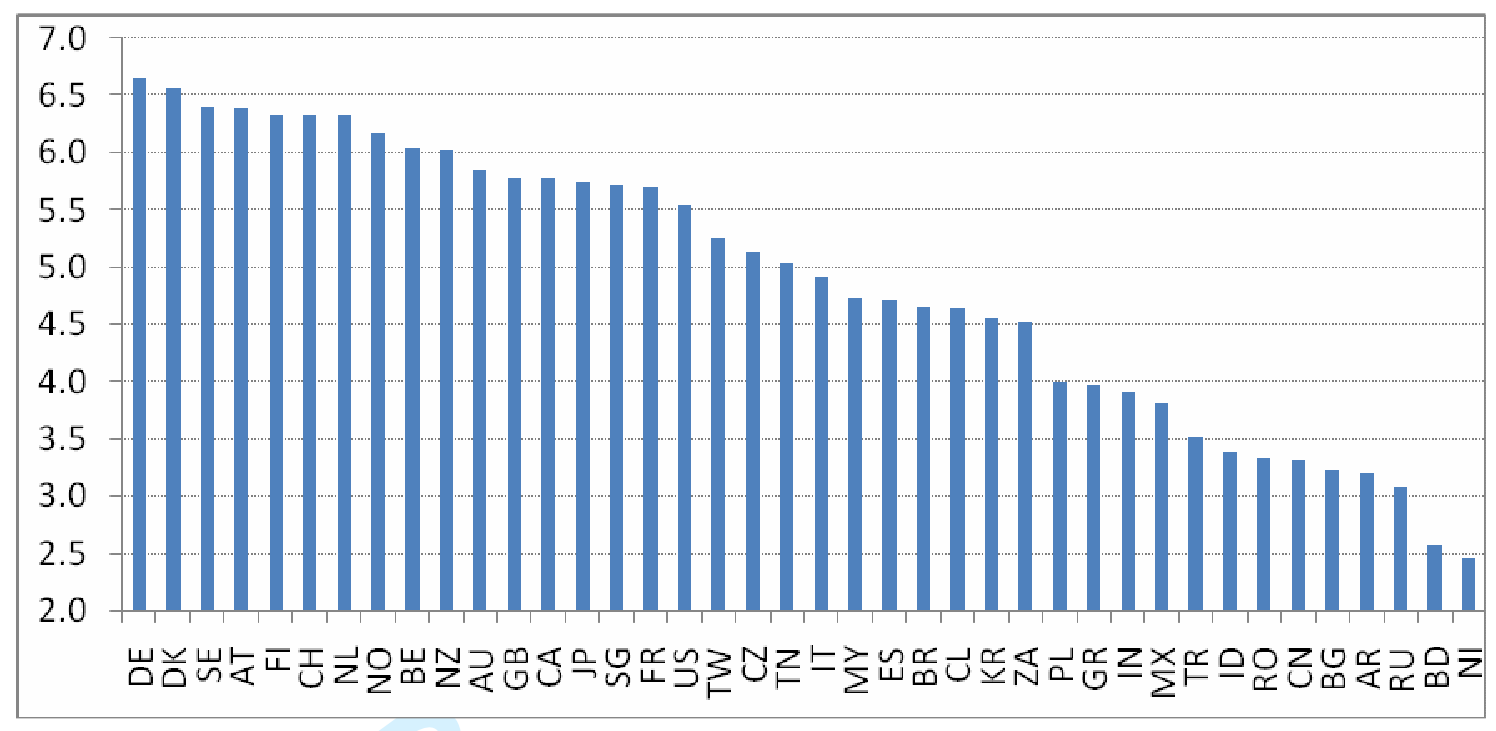

Survey question: Environmental policies in your country are $1=$ lax compared with that of most of other countries, $7=$ among the world's most stringent.

In order to assess how the information contained in this data differs from the PACE data used in most previous studies. Figure 4 provides a comparison for those countries for which both sets of data are available. On the $\mathrm{x}$-axis private sector PACE expenditures are expressed as a percentage of GDP for the year 2004 (or closest available year), ${ }^{8}$ while on the $y$-axis the mean value of the WEF index for the period 2001-2007 is given. The correlation is negative $(-0.35)$. This provides indirect confirmation of our supposition that PACE data is not reliable as a measure of environmental policy stringency.

${ }^{8}$ See OECD (2007b). 


\section{Other factors}

Figure 4. Private PACE Expenditures and WEF Stringency Index

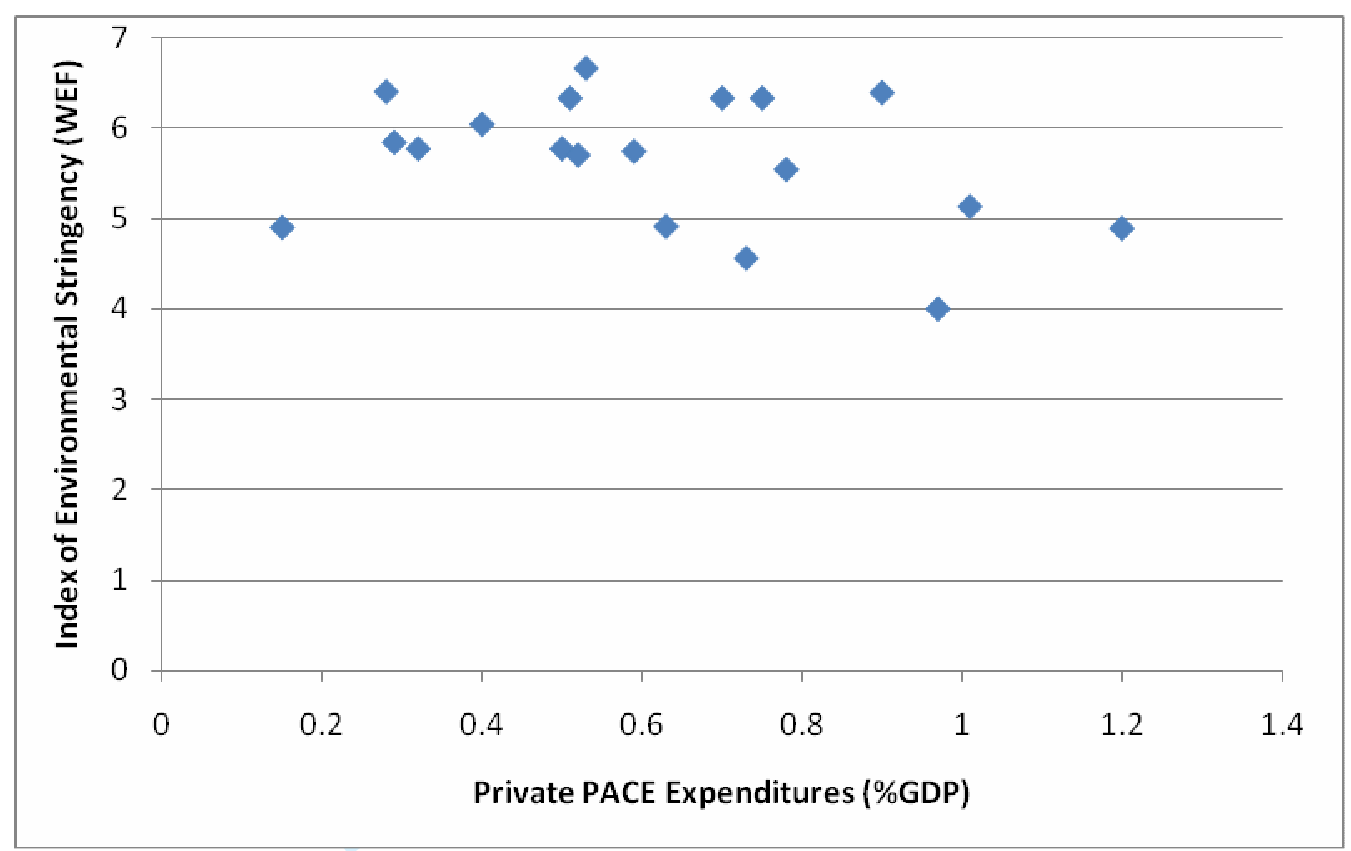

Aside from environmental policy, there are, of course, other important determinants of patenting activity for environmentally preferable technologies. This includes the propensity to invent technologies in general, as well as the propensity to protect the rents for such inventions through intellectual property (IP) rights. Factors such as general scientific capacity, market conditions, openness to trade, etc. will have an important effect on inventive activity in general, and thus also in the specific field of environmental technologies. Moreover, the propensity of inventors from a particular country to patent a given invention is likely to change over time, both because different strategies may be adopted to capture the rents from innovation (e.g., Cohen et al., 2000) and because legal conditions may change through time (e.g., Ginarte and Park, 1997).

As such, it is important to control statistically for differences in the general propensity to invent and patent inventions across countries. In the model strategy discussed below we do so in two ways. In the first instance, we include a variable reflecting the total number 
of patent applications (claimed priorities) filed across the whole spectrum of technological fields (not only environmental). In addition, we implement a two-stage strategy in which we first estimate patent totals in general since we are interested in determining the relative importance of the effects of the general policy and market context on innovation. Based upon a review of the literature ${ }^{9}$, we retain four variables as being of particular importance for the first-stage equation: $R \& D$ expenditures, openness to trade, the strength of IPR regimes and aggregate GDP.

Data on gross domestic expenditures on R\&D was obtained from OECD.Stat R\&D dataset. This has been expressed as \% of GDP. Israel, Sweden, Finland and Japan have the highest percentage of R\&D as a \% of GDP. In line with the results from previous studies, we assume that the effect of this variable will be positive. Previous evidence has also found strong evidence for the positive effects of international trade regimes on innovation. By being exposed to international competitive pressures firms will have strong incentives to innovate. In this case we use the net trade balance as a measure of exposure to international trade pressures. The data was obtained from OECD.Stat International Trade dataset. We also include an index of the strength of intellectual property rights regimes. Since firms will have greater incentives to invest in R\&D if they feel that they will be able to capture the rents from such investments it is hypothesized that the sign will be positive. This data has been obtained from Park and Lippoldt (2008), and the variable is lagged one period. And finally, we include lagged real GDP as an explanatory variable. Descriptive data on the main variables is included in Table 2.

\footnotetext{
${ }^{9}$ See, for example, Cricscuolo et al. (2005), Scherer and Harhoff (2000), Syrneonidis (1996), Gerosky (1990), Kraft (1987) and Acs and Audretsch (1987). Ulku (2007) is one of the few studies which includes a sample of both OECD and non-OECD economies. Jaumotte and Pain (2005) provide a review of the literature.
} 
Table 2. Descriptive Statistics

\begin{tabular}{|c|c|c|c|c|c|c|c|}
\hline Variable & Name & $\mathrm{N}$ & $\mathrm{n}$ & Mean & $\begin{array}{l}\text { Std.Dev. } \\
\text { (overall) }\end{array}$ & Min & $\operatorname{Max}$ \\
\hline $\begin{array}{l}\text { Environment-related } \\
\text { patents (air, water, } \\
\text { waste) } \\
\text { Index of }\end{array}$ & AWWPAT & 440 & 77 & 23.36 & 81.15 & 0 & 622 \\
\hline $\begin{array}{l}\text { Environmental } \\
\text { policy stringency } \\
\text { Total non- }\end{array}$ & POLSTRNG & 440 & 77 & 4.58 & 1.22 & 1.20 & 6.80 \\
\hline $\begin{array}{l}\text { environmental } \\
\text { patents } \\
\text { Gross domestic }\end{array}$ & TOTPAT & 440 & 77 & 1868.79 & 6461.72 & 0 & 49263 \\
\hline $\begin{array}{l}\text { Gross domestic } \\
\text { product (\$US billion) } \\
\text { Government } \\
\text { expenditures on }\end{array}$ & GDP & 191 & 32 & 1.20 & 2.20 & 0.01 & 11.27 \\
\hline R\&D (\$US million) & GERD & 191 & 32 & 1.69 & 0.90 & 0.36 & 4.17 \\
\hline $\begin{array}{l}\text { Index of intellectual } \\
\text { property rights } \\
\text { Net international }\end{array}$ & IPR & 191 & 32 & 4.24 & 0.50 & 2.76 & 4.88 \\
\hline trade ( $\$$ US billion) & TRADE & 191 & 32 & -0.97 & 11.32 & -68.11 & 22.16 \\
\hline
\end{tabular}

\section{Empirical model and results}

Our modelling strategy proceeds in two stages. In the first instance, we estimate a reduced form equation in which total patents (minus 'environmental' patents) are included directly as a control variable. In the second instance, we apply two-stage estimation in which total patents are estimated first and the fitted values are then used in the equation for environmental patents. Since the sample for which all explanatory variables are available is smaller in the latter case, for purposes of comparison we reestimate the first model on the reduced sample.

The initial reduced form model takes the form:

$$
E\left(\text { AWWPAT }_{i, t}\right)=\exp \left(\beta_{1} \text { POLSTRING }_{i, t}+\beta_{2} \text { TOTALPAT }_{i, t}+\alpha_{t}+\varepsilon_{i, t}\right)
$$


where $i$ indicates the inventor country and $t$ the priority year. The dependent variable $A W W P A T_{i, t}$ is the count of high-value patents ('claimed priorities') related to the environment. POLSTRING ${ }_{i, t}$ reflects the perceived stringency of the environmental policy regime. TOTALPAT ${ }_{i, t}$ is the total number of high-value patents in all other technology fields. Finally, year fixed effects $\left(\alpha_{t}\right)$ account for omitted time-variant effects that influence all countries in the same way. All the residual variation is captured by the error term $\left(\varepsilon_{i, t}\right)$. Convergence problems and little variation of our policy variables over time prevent us from including country fixed effects. However, a dummy variable indicating whether the country is a member of the OECD is included in two of the models estimated. Given the count nature of the dependent variable, a negative binomial model is used to estimate the model (for details on count data models see e.g., Cameron and Trivedi, 1998; Maddala, 1990; Hausman, Hall and Griliches 1984).

Table 3 reports the results from the estimation of the reduced-form model of environmental innovation presented above using a panel of 77 countries over the period 2001-2007. The estimate of POLSTRNG is always positive and significant no matter whether we include time fixed effects and the OECD dummy variable or not. This result confirms previous evidence (e.g. Lanjouw and Mody, 1996 and Brunnermeier and Cohen, 2003). 
Table 3. Policy Stringency and Environmental Patents (2001-2007) ${ }^{10}$

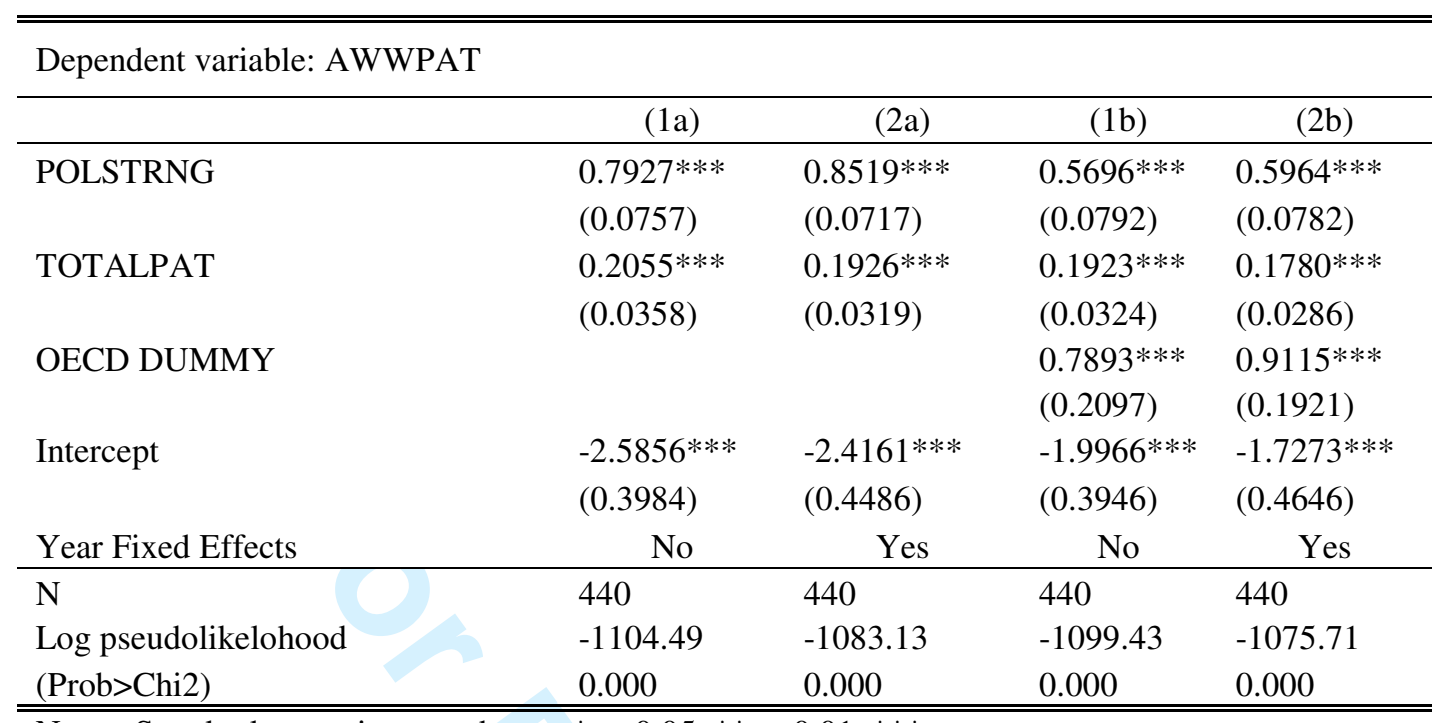

Notes: Standard errors in parentheses, $* \mathrm{p}<0.05, * * \mathrm{p}<0.01, * * *$ $\mathrm{p}<0.001$.

It is also interesting to examine whether the effect of policy stringency on innovation differs across country types. In order to assess whether or not this is the case the policy stringency variables were interacted with two different variables: the binary variable indicating whether or not the country is a member of the OECD (models $1 \mathrm{c}$ and $2 \mathrm{c}$ in Table 4); and, a three-class variable which distinguishes between countries in terms of the $\%$ of government expenditures on R\&D in total GDP (GERD) (models $1 \mathrm{~d}$ and $2 \mathrm{~d}$ in Table 4). ${ }^{11}$

\footnotetext{
${ }^{10}$ The estimation sample of 440 observations includes a panel of 7 years (2001-2007) and 77 countries, including: 34 OECD member countries (Australia, Austria, Belgium, Canada, Chile, Czech Republic, Denmark, Estonia, Finland, France, Germany, Greece, Hungary, Iceland, Ireland, Israel, Italy, Japan, Korea, Luxembourg, Mexico, Netherlands, New Zealand, Norway, Poland, Portugal, Slovakia, Slovenia, Spain, Sweden, Switzerland, Turkey, United Kingdom, USA); and 43 non-OECD countries (Algeria, Argentina, Bangladesh, Bolivia, Bosnia and Herzegovina, Brazil, Bulgaria, Chinese Taipei, Colombia, Croatia, Cyprus, Ecuador, El Salvador, Georgia, Haiti, Hong Kong SAR, India, Indonesia, Jamaica, Kenya, Latvia, Lithuania, Macedonia FYR, Malaysia, Morocco, Nigeria, Panama, China, Peru, Philippines, Romania, Russia,

Singapore, South Africa, Tanzania, Thailand, Trinidad and Tobago, Tunisia, Ukraine, United Arab Emirates, Venezuela, Vietnam, Zimbabwe).

${ }^{11}$ The GERD/GDP ratio $=0.91 \%$ and $1.88 \%$ correspond to the 33th and 66th percentiles, respectively. In this case the sample is smaller since data on GERD is missing for some observations. The estimation sample of 271 observations includes a panel of 7 years (2001-2007) and 39 countries, including: 32 OECD member countries (excl. Chile, Estonia); and 7 non-OECD countries (incl. Argentina, Chinese Taipei, China, Romania, Russia, Singapore, South Africa).
} 
Table 4. Effect of Policy Stringency by Country Type and Environmental Patents (2001-2007)

\begin{tabular}{lllll}
\hline \hline Dependent variable: AWWPAT & \multicolumn{1}{c}{$(1 \mathrm{c})$} & \multicolumn{1}{c}{$(2 \mathrm{c})$} & \multicolumn{1}{c}{$(1 \mathrm{~d})$} & \multicolumn{1}{c}{$(2 \mathrm{~d})$} \\
\hline POLSTRNG * OECD & $0.6249^{* * *}$ & $0.6681^{* * *}$ & & \\
& $(0.0795)$ & $(0.0763)$ & & \\
POLSTRNG * Non-OECD & $0.4280^{* * *}$ & $0.4495^{* * *}$ & & \\
& $(0.1001)$ & $(0.0944)$ & & \\
POLSTRNG * Low GERD/GDP ratio $(<0.91 \%)$ & & & $0.2404^{* * *}$ & $0.1855^{*}$ \\
& & & $(0.0939)$ & $(0.0898)$ \\
POLSTRNG * Medium GERD/GDP ratio & & & $0.4376^{* * *}$ & $0.3801^{* * *}$ \\
& & & $(0.0846)$ & $(0.0857)$ \\
POLSTRNG * High GERD/GDP ratio $(>1.88 \%)$ & & & $0.4702^{* * *}$ & $0.4531^{* * *}$ \\
& & & $(0.0744)$ & $(0.0770)$ \\
TOTPAT & $0.1905^{* * *}$ & $0.1765^{* * *}$ & $0.1380^{* * *}$ & $0.1210^{* * *}$ \\
& $(0.0323)$ & $(0.0286)$ & $(0.0184)$ & $(0.0160)$ \\
OECD dummy & & & 0.4042 & $0.5586^{*}$ \\
& & & $(0.2509)$ & $(0.2324)$ \\
Intercept & $-1.4932^{* * *}$ & $-1.2096^{*}$ & -0.5232 & 0.0588 \\
& $(0.4419)$ & $(0.4918)$ & $(0.3865)$ & $(0.4243)$ \\
Year fixed effects & - & Yes & - & Yes \\
\hline $\mathrm{N}$ & 440 & 440 & 271 & 271 \\
Log pseudolikelihood & -1098.01 & -1074.25 & -901.09 & -868.54 \\
(Prob>Chi2) & 0.000 & 0.000 & 0.000 & 0.000 \\
\hline \hline
\end{tabular}

The results indicate that the effect of policy stringency is greater for OECD countries than for non-OECD countries. In addition, there is a complementary role between policy stringency and government expenditures on $R \& D$. This is particularly evident as one shifts from low-GERD economies to medium-GERD economies.

In order to ensure that the estimate of $\beta_{1}$ is not biased we then proceed to estimate environmental patents in two stages. In the first stage, total patents are estimated with a model of the following form:

$$
E\left(\text { TOTALPAT }_{i, t}\right)=\exp \left(\beta_{1} G D P_{i, t-1}+\beta_{2} G E R D_{i, t}+\beta_{3} I P R_{i, t-1}+\beta_{4} \operatorname{TRADE}_{i, t}+\varepsilon_{i, t}\right)
$$

In Table 5 we present the results from the first-stage regression of total patents (TOTALPATENTS) on lagged gross domestic product $\left(\mathrm{GDP}_{\mathrm{t}-1}\right)$ and an index of the strength of property rights protection $\left(\mathrm{IPR}_{\mathrm{t}-1}\right)$, gross domestic expenditure on $\mathrm{R} \& \mathrm{D}$ 
Table 5. Determinants of Total Patents (2001-2007)

\begin{tabular}{ll}
\hline \hline Dependent variable: TOTPAT & $0.7109 * * *$ \\
\hline GDP & $(0.0614)$ \\
& $0.6813^{* * *}$ \\
GERD & $(0.1288)$ \\
& $1.6138^{* * *}$ \\
IPR & $(0.1679)$ \\
& $0.0756^{* * *}$ \\
TRADE & $(0.0104)$ \\
& $-2.1607 * * *$ \\
Intercept & $(0.5679)$ \\
& 191 \\
\hline $\mathrm{N}$ & -1452.89 \\
Log pseudolikelihood & 0.000 \\
(Prob $>$ Chi2) & Notes: Standard errors in parentheses, ${ }^{*} \mathrm{p}<0.05, * * \mathrm{p}<0.01, * * * \mathrm{p}<0.001$. \\
\end{tabular}

From this model we retain the fitted values of total patents and use them as an explanatory variable in the second-stage of the regression on AWWPATENTS:

$$
E\left(\text { AWWPAT }_{i, t}\right)=\exp \left[\beta_{1} \text { POLSTRNG }_{i, t}+\beta_{2} \operatorname{TOTALPAT}_{(F I T)_{i, t}}+\alpha_{t}+\varepsilon_{i, t}\right]
$$

In Table 6 we compare the results with the predicted values of total patents (columns 1 and 3) and the observed TOTALPATENT variable (columns 2 and 4) as regressors, using the same sample, with and without year fixed effects. Although the coefficient of the predicted total patents is smaller in magnitude, the expected positive sign and statistical significance persist. The findings suggest that an estimation of the reduced-form model, where total patents are considered to be exogenous, provides closely comparable results with those of the two-stage estimation. Given the much larger sample size used in the reduced-form equation, this is our preferred model. 
Table 6. Second-Stage Regression of Environmental Innovation on Stringency

\begin{tabular}{lllll}
\hline \hline & $\begin{array}{c}\text { Predicted } \\
\text { total } \\
\text { patents } \\
(1)\end{array}$ & $\begin{array}{c}\text { Observed } \\
\text { total } \\
\text { patents } \\
(2)\end{array}$ & $\begin{array}{c}\text { Predicted } \\
\text { total } \\
\text { patents } \\
(3)\end{array}$ & $\begin{array}{c}\text { Observed } \\
\text { total } \\
\text { patents } \\
(4)\end{array}$ \\
\hline POLendent variable: AWWPAT & $\begin{array}{c}0.8085^{* * *} \\
(0.10407)\end{array}$ & $\begin{array}{c}0.5075^{* * *} \\
(0.07634)\end{array}$ & $\begin{array}{c}0.8200^{* * *} \\
(0.09496)\end{array}$ & $\begin{array}{c}0.5301 * * * \\
(0.07142)\end{array}$ \\
TOTPAT & & $0.1353^{* * *}$ & & $0.1292^{* * *}$ \\
& & $(0.01632)$ & & $(0.01559)$ \\
TOTPAT(FIT) & $0.0671^{* * *}$ & & $0.0710^{* * *}$ & \\
& $(0.01882)$ & & $(0.01806)$ & \\
Intercept & $-1.5824 * *$ & -0.4710 & $-1.2896 *$ & -0.2760 \\
& $(0.52634)$ & $(0.41744)$ & $(0.56038)$ & $(0.46053)$ \\
Time fixed effects & - & - & Yes & Yes \\
\hline $\mathrm{N}$ & 191 & 191 & 191 & 191 \\
Log pseudolikelihood & -755.22 & -714.39 & -733.51 & -700.07 \\
(Prob>Chi2) & 0.000 & 0.000 & 0.000 & 0.000 \\
\hline \hline
\end{tabular}

What do these results mean in concrete terms? Based on the calculation of the marginal effects for the models presented in Tables 3 and 4 a one unit increase in stringency would yield between 1.5 and 4.5 more AWW patents, on average. Since the sample mean of AWW patents is 23.36 , this represents about a 6-19\% increase. 'Neighbouring' country pairs which are one unit apart with respect to their mean index ranking include: ${ }^{12}$ Germany-France; Mexico-Peru; Chinese-Taipei; and, Norway-Czech Republic. Similarly, an example of a 'ladder' of increasing stringency (at one unit distance) is Nigeria -> Turkey $->$ Korea -> US -> Demark.

In summary, because a more stringent policy induces more innovation, then by imposing a price (whether explicitly or implicitly) on the costs of pollution emissions, or by otherwise changing the opportunity costs associated with environmental assets, environmental policy is likely to induce innovation because firms seek to meet the policy objectives at least cost.

${ }^{12}$ The country with the higher ranking is listed first. 


\section{Discussion and Conclusions}

This paper examines the impact of perceived environmental policy stringency on innovations in environment-related technology. In order to test our main hypothesis - that more stringent environmental policies induce technological innovation - an unbalanced panel of 77 countries across seven years is developed based upon data from the PATSTAT database and World Economic Forum's Executive Opinion Survey. A reduced-form equation is estimated on a sample of 440 observations. In order to address possible concerns about endogeneity (between general and environmental innovation), a two-stage model is also estimated on a smaller sample of 191 observations.

The results of both models confirm our hypothesis that greater policy stringency has a positive effect on environmental innovation. This is a reassuring result insofar as it implies that the cost of meeting environmental objectives may be offset (at least partly) by the innovations induced. While it would be tempting to conclude from this finding that there are 'win wins' associated with the introduction of environmental policies, such a conclusion is unwarranted. While emission-saving innovation may be induced by stringent policies, the cost of such innovation and thus the impacts on economic performance have not been assessed. Indeed, work undertaken based on survey data finds that perceived environmental policy stringency has a positive effect on innovation, but a negative impact on commercial performance (see Lanoie et al. 2010). 


\section{REFERENCES}

Acs, Z. and D. Audretsch. (1987) Innovation, Market Structure, and Firm Size, Review of Economics and Statistics 69, 567-574.

Brunnermeier, S.B. and M.A. Cohen. (2003) Determinants of environmental innovation in US manufacturing industries, Journal of Environmental Economics and Management 45, 278-293.

Cameron, A.C. and P.K. Trivedi. (1998) Regression analysis of count data. Cambridge University Press, Cambridge.

Cohen, W.M., R.R. Nelson and J.P. Walsh. (2000) Protecting their intellectual assets: Appropriability conditions and why U.S. manufacturing firms patent (or not), NBER Working Paper \#7552.

Crabb, J.M. and D.K.N. Johnson (2007) Fueling the Innovation Process: Oil Prices and Induced Innovation in Automotive Energy-Efficient Technology, Working Paper, Colorado Department of Economics and Business, May 2007.

Criscuolo, C., Haskel, J.E., and M.J. Slaughter (2005) Global Engagement and the Innovation Activities of Firms, NBER Working Paper No. 11479.

Dernis, H. and D. Guellec. (2001) Using patent counts for cross-country comparisons of technology output, STI mimeo, Organisation for Economic Co-operation and Development, Paris, France. (http://www.oecd.org/dataoecd/26/11/21682515.pdf).

Downing, P.B., and L.J. White. (1986) Innovation in pollution control, Journal of Environmental Economics and Management 13, 18-29.

EPO (European Patent Office) (2008). Worldwide Patent Statistical Database (PATSTAT), October 2008 version.

Fischer C. and R.G. Newell. (2008) Environmental and technology policies for climate mitigation, Journal of Environmental Economics and Management 55, 142-162.

Gerosky, P. (1990) Innovation, Technological Opportunity and Market Structure, Oxford Economic Papers 42, 586-602.

Ginarte, J.C. and W. Park. (1997) Determinants of patent rights: A cross-national study, Research Policy 26, 283-301.

Griliches, Z. (1990) Patent statistics as economic indicators: A survey, Journal of Economic Literature 28, 1661-1707.

Guellec, D. and B. van Pottelsberghe de la Potterie (2000) Applications, Grants and the Value of a Patent" Economics Letters 69, 109-114.

Harhoff, D., Scherer, F.M., and K. Vopel (2003). Citations, family size, opposition and the value of patent rights Research Policy 32, 1343-63. 
Hausman, J., Hall, B.H., and Z. Griliches. (1984). Econometric models for count data with an application to the patents-R\&D relationship, Econometrica 52, 909-938.

Hicks, J.R. (1932). The theory of wages. Macmillan, London.

Jaffe, A.B, Newell, R., and R.N. Stavins. (2002) Technological change and the environment, Environmental and Resources Economics 22, 41-69.

Jaffe, A.B. and K. Palmer. (1997) Environmental regulation and innovation: A panel data study, The Review of Economics and Statistics 79, 610-619.

Jaumotte, F. and N. Pain. (2005) From Ideas to Development: The Determinants of R\&D and Patenting, OECD Economics Department Working Paper No. 457. (http://www.olis.oecd.org/olis/2005doc.nsf/LinkTo/NT0000473A/\$FILE/JT001954 20.pdf)

Johnstone N., Haščič I., and D. Popp (2010) Renewable energy policies and technological innovation: Evidence based on patent counts, Environmental and Resource Economics 45, 133-155.

Johnstone, N. (2007) Environmental Policy and Corporate Behaviour. Cheltenham, UK: Edward Elgar.

Kneese A.V. and C.L. Schultze. (1977) Pollution, prices and public policy, The American Political Science Review 71, 1187-89.

Kraft, K. (1987) Market Structure, Firm Characteristics and Innovative Activity Journal of Industrial Economics 37, 329-336.

Lanjouw, J.O. and A. Mody. (1996) Innovation and the international diffusion of environmentally responsive technology Research Policy 25, 49-571.

Lanoie, P., Laurent-Lucchetti J., Johnstone N., and S. Ambec. (2010) Environmental Policy, Innovation and Performance: New Insights on the Porter Hypothesis, Cirano Discussion Paper 2007s-19.

Maddala, G.S. (1983). Limited-dependent and qualitative variables in econometrics. Cambridge University Press, Cambridge.

Madsen, J.B. (2007) Are there diminishing returns to R\&D? Economic Letters 95, 161-166.

Milliman, S.R. and R. Prince. (1989) Firm incentives to promote technological change in pollution control, Journal of Environmental Economics and Management 17, 247-265.

OECD (2007a) OECD Environmental Data: Compendium 2006/2007. OECD, Paris.

OECD. (2007b) Pollution abatement and control expenditure in OECD countries: A report for the Working Group on Environmental Information and Outlooks. OECD Environment Directorate Working Paper. OECD, Paris. 
OECD (2008) Environmental Policy, Technological Change and Patents, OECD, Paris.

OECD (2009) OECD Patent Statistics Manual. OECD, Paris.

Park, W., and Lippoldt, D. (2008) "Technology Transfer and the Economic Implications of the Strengthening of Intellectual Property Rights in Developing Countries", Trade Policy Working Paper no. 62, OECD, Paris

Popp, D. (2006) International Innovation and Diffusion of Air Pollution Control Technologies: The Effects of NOX and SO2 Regulation in the U.S., Japan, and Germany, Journal of Environmental Economics and Management 51, 46-71.

Popp, D., Newell, R.G. and Jaffe, A.B. (2009) Energy, the Environment, and Technological Change. NBER Working Paper No. 14832.

Popp, D., T. Hafner and N. Johnstone. (2007). Policy vs. consumer pressure: Innovation and diffusion of alternative bleaching technologies in the pulp industry. NBER Working Paper \#13439.

Scherer, F. and D. Harhoff (2000) Technology Policy for a World of Skewed Distributed Outcomes Research Policy 29, 559-566.

Schmoch, U. (2003) Definition of patent search strategies for selected technological areas: Report to the OECD, mimeo, Frauenhofer ISI, Karlsruhe, Germany.

Syrneonidis, G. (1996) Innovation, Firm Size and Market Structure: Schumpeterian Hypotheses and Some New Themes, OECD Economic Studies 27, 35-70.

Ulku, H. (2007) R\&D, Innovation and Output: Evidence from OECD and non-OECD Countries, Applied Economics, 39, 291-307.

Vollebergh, H. (2007) Impacts of environmental policy instruments on technological change, OECD Environment Directorate Working Paper .

WEF (World Economic Forum). 2008. Global Competitiveness Report 2007-2008. Oxford University Press, New York. (http://www.weforum.org/en/initiatives/gcp/index.htm) 


\section{Annex 1. Patent classes for selected areas of environmental technology}

\begin{tabular}{|c|c|}
\hline AIR POLLUTION & IPC Class \\
\hline $\begin{array}{l}\text { Filters or filtering processes specially modified for separating dispersed particles from gases or } \\
\text { vapours }\end{array}$ & B01D46 \\
\hline Separating dispersed particles from gases, air or vapours by liquid as separating agent & B01D47 \\
\hline Separating dispersed particles from gases, air or vapours by other methods & B01D49 \\
\hline Combinations of devices for separating particles from gases or vapours & B01D50 \\
\hline Auxiliary pretreatment of gases or vapours to be cleaned from dispersed particles & B01D51 \\
\hline Chemical or biological purification of waste gases; by catalytic conversion & B01D53/34-36 \\
\hline Chemical or biological purification of waste gases; Removing components of defined structure & B01D53/46-72 \\
\hline Separating dispersed particles from gases or vapour, e.g. air, by electrostatic effect & B03C3 \\
\hline Use of additives to fuels or fires for particular purposes for reducing smoke development & C10L10/02 \\
\hline Use of additives to fuels or fires for particular purposes for facilitating soot removal & C10L10/06 \\
\hline Blast furnaces; Dust arresters & $\mathrm{C} 21 \mathrm{~B} 7 / 22$ \\
\hline $\begin{array}{l}\text { Manufacture of carbon steel, e.g. plain mild steel, medium carbon steel, or cast-steel; Removal } \\
\text { of waste gases or dust }\end{array}$ & $\mathrm{C} 21 \mathrm{C} 5 / 38$ \\
\hline $\begin{array}{l}\text { Exhaust or silencing apparatus having means for purifying, rendering innocuous, or otherwise } \\
\text { treating exhaust }\end{array}$ & F01N3 \\
\hline $\begin{array}{l}\text { Exhaust or silencing apparatus combined or associated with devices profiting by exhaust } \\
\text { energy }\end{array}$ & F01N5 \\
\hline Exhaust or silencing apparatus, or parts thereof & F01N7 \\
\hline Electrical control of exhaust gas treating apparatus & F01N9 \\
\hline Monitoring or diagnostic devices for exhaust-gas treatment apparatus & F01N11 \\
\hline $\begin{array}{l}\text { Combustion apparatus characterised by means for returning flue gases to the combustion } \\
\text { chamber or to the combustion zone }\end{array}$ & F23B80 \\
\hline $\begin{array}{l}\text { Combustion apparatus characterised by arrangements for returning combustion products or } \\
\text { flue gases to the combustion chamber }\end{array}$ & F23C9 \\
\hline $\begin{array}{l}\text { Arrangements of devices for treating smoke or fumes of purifiers, e.g. for removing noxious } \\
\text { material }\end{array}$ & F23J15 \\
\hline Shaft or like vertical or substantially vertical furnaces; Arrangements of dust collectors & F27B1/18 \\
\hline $\begin{array}{l}\text { Alarms responsive to a single specified undesired or abnormal condition and not otherwise } \\
\text { provided for, e.g. pollution alarms; toxics }\end{array}$ & G08B21/12-14 \\
\hline $\begin{array}{l}\text { Incinerators or other apparatus specially adapted for consuming specific waste or low grade } \\
\text { fuels; of waste gases or noxious gases }\end{array}$ & F23G7/06 \\
\hline
\end{tabular}

\begin{tabular}{|l|l|}
\hline \multicolumn{1}{|c|}{ WATER POLLUTION } & IPC Class \\
\hline \hline Arrangements of installations for treating waste-water or sewage & B63J4 \\
\hline Treatment of water, waste water, sewage or sludge & C02F \\
\hline Fertilisers from waste water, sewage sludge, sea slime, ooze or similar masses & C05F7 \\
\hline Chemistry; Materials for treating liquid pollutants, e.g. oil, gasoline, fat & C09K3/32 \\
\hline $\begin{array}{l}\text { Devices for cleaning or keeping clear the surface of open water from oil or like floating } \\
\text { materials by separating or removing these materials; Barriers therefor }\end{array}$ & E02B15/04-06 \\
\hline $\begin{array}{l}\text { Cleaning or keeping clear the surface of open water; Devices for removing the material from } \\
\text { the surface }\end{array}$ & E02B15/10 \\
\hline $\begin{array}{l}\text { Methods or installations for obtaining or collecting drinking water or tap water; Rain, surface } \\
\text { or groundwater }\end{array}$ & E03B3 \\
\hline Plumbing installations for waste water & E03C1/12 \\
\hline Sewers - Cesspools & E03F \\
\hline Fertilisers from waste water, sewage sludge, sea slime, ooze or similar masses & C05F7 \\
\hline \hline
\end{tabular}




\begin{tabular}{|c|c|}
\hline SOLID WASTE & IPC Class \\
\hline $\begin{array}{l}\text { Animal feeding-stuffs from distillers' or brewers' waste; waste products of dairy plant; meat, } \\
\text { fish, or bones; from kitchen waste }\end{array}$ & A23K1/06-10 \\
\hline Footwear made of rubber waste & A43B $1 / 12$ \\
\hline Heels or top-pieces made of rubber waste & A43B21/14 \\
\hline Medical or veterinary science; Disinfection or sterilising methods specially adapted for refuse & A61L11 \\
\hline $\begin{array}{l}\text { Separating solid materials; General arrangement of separating plant specially adapted for } \\
\text { refuse }\end{array}$ & B03B $9 / 06$ \\
\hline Disposal of solid waste & B09B \\
\hline Reclamation of contamined soil & B09C \\
\hline Manufacture of articles from scrap or waste metal particles & B22F8 \\
\hline $\begin{array}{l}\text { Sawing tools for saw mills, sawing machines, or sawing devices; Edge trimming saw blades or } \\
\text { tools combined with means to disintegrate waste }\end{array}$ & B27B33/20 \\
\hline Recovery of plastics or other constituents of waste material containing plastics & B29B17 \\
\hline Preparing material; Recycling the material & B29B7/66 \\
\hline Presses specially adapted for consolidating scrap metal or for compacting used cars & B30B9/32 \\
\hline Systematic disassembly of vehicles for recovery of salvageable components, e.g. for recycling & B62D67 \\
\hline Transporting; Gathering or removal of domestic or like refuse & $\mathrm{B} 65 \mathrm{~F}$ \\
\hline Stripping waste material from cores or formers, e.g. to permit their re-use & B65H73 \\
\hline Hydraulic cements from oil shales, residues or waste other than slag & C04B7/24-30 \\
\hline $\begin{array}{l}\text { Calcium sulfate cements starting from phosphogypsum or from waste, e.g. purification } \\
\text { products of smoke }\end{array}$ & C04B11/26 \\
\hline $\begin{array}{l}\text { Use of agglomerated or waste materials or refuse as fillers for mortars, concrete or artificial } \\
\text { stone; Waste materials or Refuse }\end{array}$ & C04B18/04-10 \\
\hline Clay-wares; Waste materials or Refuse & C04B33/132 \\
\hline Fertilisers from household or town refuse & C05F9 \\
\hline Recovery or working-up of waste materials & C08J11 \\
\hline $\begin{array}{l}\text { Luminescent, e.g. electroluminescent, chemiluminescent, materials; Recovery of luminescent } \\
\text { materials }\end{array}$ & C09K11/01 \\
\hline Production of liquid hydrocarbon mixtures from rubber or rubber waste & C10G1/10 \\
\hline $\begin{array}{l}\text { Solid fuels essentially based on materials of non-mineral origin; on sewage, house, or town } \\
\text { refuse; on industrial residues or waste materials }\end{array}$ & C10L5/46-48 \\
\hline Working-up used lubricants to recover useful products & C10M175 \\
\hline $\begin{array}{l}\text { Working-up raw materials other than ores, e.g. scrap, to produce non-ferrous metals or } \\
\text { compounds thereof }\end{array}$ & $\mathrm{C} 22 \mathrm{~B} 7$ \\
\hline Obtaining zinc or zinc oxide; From muffle furnace residues; From metallic residues or scraps & C22B $19 / 28-30$ \\
\hline Obtaining tin; From scrap, especially tin scrap & $\mathrm{C} 22 \mathrm{~B} 25 / 06$ \\
\hline $\begin{array}{l}\text { Mechanical treatment of natural fibrous or filamentary material to obtain fibres or filament; } \\
\text { Arrangements for removing, or disposing of, tow or waste }\end{array}$ & D01B5/08 \\
\hline Textiles; Disintegrating fibre-containing articles to obtain fibres for re-use & D01G11 \\
\hline Textiles; Arrangements for removing, or disposing of, noil or waste & D01G19/22 \\
\hline $\begin{array}{l}\text { Paper-making; Fibrous raw materials or their mechanical treatment ; the raw material being } \\
\text { waste paper or rags }\end{array}$ & $\mathrm{D} 21 \mathrm{~B} 1 / 08$ \\
\hline $\begin{array}{l}\text { Paper-making; Fibrous raw materials or their mechanical treatment; Defibrating by other } \\
\text { means of waste paper }\end{array}$ & $\mathrm{D} 21 \mathrm{~B} 1 / 32$ \\
\hline Paper-making; Other processes for obtaining cellulose; Working-up waste paper & D21C5/02 \\
\hline Paper-making; Pulping; Non-fibrous material added to the pulp; Waste products & D21H17/01 \\
\hline
\end{tabular}




\begin{tabular}{|l|l|}
$\begin{array}{l}\text { Street cleaning; Apparatus equipped with, or having provisions for equipping with, both } \\
\text { elements for removal of refuse or the like and elements for removal of snow or ice }\end{array}$ & E01H6 \\
\hline $\begin{array}{l}\text { Street cleaning; Removing undesirable matter, e.g. rubbish, from the land, not otherwise } \\
\text { provided for }\end{array}$ & E01H15 \\
\hline $\begin{array}{l}\text { Cremation furnaces; Incineration of waste; Incinerator constructions; Details, accessories or } \\
\text { control therefor }\end{array}$ & F23G5 \\
\hline $\begin{array}{l}\text { Cremation furnaces; Incinerators or other apparatus specially adapted for consuming specific } \\
\text { waste or low grade fuels }\end{array}$ & F23G7 \\
\hline \hline
\end{tabular}

